\title{
ECONOMIC FREEDOM AND ENTREPRENEURIAL ACTIVITY: EVIDENCE FROM EU 11 COUNTRIES
}

\author{
Dragan Mandić \\ JU Economic School Banja Luka, Bosnia and Herzegovina \\ Zoran Borović \\ Faculty of Economics, University of Banja Luka, Bosnia and Herzegovinag \\ Mladen Jovićević \\ Maksima trejd d.o.o. Banja Luka, Bosnia and Herzegovina
}

date of paper receipt:

30.08.2017.

Review paper date of sending to review:

12.09.2017. date of review receipt:

23.09.2017.

\section{SUMMARY}

In this paper, we will present the results of our survey on economic freedom and entrepreneurial activity. We have conducted our analysis on EU 11countries (Belgium, Denmark, France, Germany, Greece, Ireland, Italy, Netherlands, Spain, Sweden and United Kingdom) for the time period 20002014. To measure the entrepreneurial activity we have used data from the Global Entrepreneurship Monitor, and to measure economic freedom, we have used data from Fraiser Institute. Our results suggest strong positive and statistically significant, long term impact of economic freedom on entrepreneurial activity.

Keywords: Institutional framework, Economic freedom, the entrepreneurial activity,

\section{INTRODUCTION}

In this paper, we will investigate the empirical relationship between the degree of economic freedom and the entrepreneurial activity. We will conduct our research on $11 \mathrm{EU}$ countries (Belgium, Denmark, France, Germany, Greece, Ireland, Italy, Netherlands, Spain, Sweden and united Kingdom) for the time period 2000-2015. The main idea was to test the link between the degree of economic freedom and the entrepreneurial activity on 15 EU countries (Countres which were EU members before the great expansion in 2004). Due to objective lack of data, the sample was reduced to 11 countries. Our goal is to investigate the quality of institutional framework for the countries, which can be described as a core capitalist countries, and to test the impact of the institutional framework on the entrepreneurial activity.

Entrepreneurship is the act of exploiting an opportunity for profit. It is the exploitation of profit opportunities in the private sector that drives economic progress forward, which is why so many policy makers at the local, state, and national levels seem to be focused on spurring entrepreneurial activity. The entrepreneurs can see the situation differently than others, and they have the freedom to act on their vision. Without the freedom to act, or vision to pursue, the entrepreneurship can not exist. We will investigate this relationship very closelly. We will use data from The Global Entrepreneurship Research Association in its GEM reports (Global Entrepreneurship Monitor) and the economic freedom index published by The Heritage Foundation and Fraiser Institute. 
The paper is arranged as follows. The first part of the paper provides the overview of the previous research. The second part of the paper refers to the research methodology and collecting data. The thirth part contains the results of the econometric analysis. The final part presents the conclusions.

\section{THEORETICAL BACKGROUND}

More recently, a few studies have investigated the relationship between economic freedom and entrepreneurship. Kreft and Sobel (2005) have investigated the relationship between the economic freedom and sole-proprietorship growth rates in US in a cross sectional study. They results confirm positive corelation. In 2008. Sobel has conducted a research to empiricaly test the Baumols hypothesis in the US. He finds that not only the productive enterpreneurship is enhanced by economic freedom, but destructive enterpreneurship is reduced. To mesure productive enterpreneurship, Sobel uses birthrates, patents, venture capital and sole-proprietorship growth rates. Hal, Pulito and VanMetre (2013) argues that economic freedom is more imortant than personal freedom, and that fiscal policy is more important than regulatory policy in affecting enterpreneurship. To measure economic freedom, they use a William Ruger and Jason Sorens developed a state-based measure of overall freedom for the Mercatus Center called the Freedom in the 50 States index, which includes measures of both personal and economic freedoms. The survey based on 21 OECD country has been conducted by Sobel et al. The results shows positive impact of economic freedom on private sector entrepreneurial activity. The research includes the other controling variables as administrative burden for start-ups, and the average level of tariffs. Both of these variables have a negative impact on private sector entrepreneurial activity.

Bjørnskov and Foss (2008) analyze the relationship between economic freedomand entrepreneurship, based on 29 countries. Most of these countries are developed countries. They argue that the smaller the size of the government will result in higher entrepreneurial activity. The results shows that both opportunity based and necessity based entrepreneurship are affected in this direction, but the effect is substantially greater on opportunity based entrepreneurship. They find that access to sound money have a similarly strong positive effect on both forms of entrepreneurship. In 2008 Nyström has conducted a panel data study of 23 OECD countries for the period 1972-2002. Nyström uses an economic freedom inedx published by the Frasier Institute. To measure enterpreneural activity, Nyström use self-employment rates as a proxy for entrepreneurship. The results shows that three out of the five components of the economic freedom index are found to have statistically significant coefficients. The variables with positive and statistically significant coefficients are: smaller government, better legal structure and more secure property rights, and less regulation on credit, labor and business sectors.

\section{MODEL AND METHODOLOGY}

For purpose of this survey we chose the following equation:

Dependent variable is defined as logarithm of a measure called "Total early-stage entrepreneurial activity" (TEA), which is defined as country shares of population aged 18-64 that have been owners and managers of a new business between 3 to 42 months. Model consists one explanatory variable and three controling variables. The three ccontroling variables are:

GDP per capita based on purchasing power parity (PPP) GDP using international dollars, Growth rate of GDP in constant prices,

The age dependency ratio

The GDP per capita is included as a control variable to explain the impact of economic freedom on entrepreneurial activity in countries with diferent economic development. The GDP growth rate is 
calculated as a first logarithmic diference of GDP in constant prices and it should correct fluctuations in opportunities for entrepreneurship caused by the business cycle. Verheul et al. (2002), claim that the supply side of entrepreneurship is dominated by the demographic composition of a country. Other studies have found that younger people are less likely to be self-employed (Peters et al., 1999), and that most start-ups are by individuals in their thirties and forties (Evans and Leighton, 1989; Storey, 1994; and van Gelderen, 1999). For this reasons, it appears important to control for the age structure. To control age structure, we will use the age dependency ratio from the World Bank. It is the ratio of dependents, i.e. people younger than 15 or older than 64, to the working-age population ages 15 to 64 . The data is presented as the proportion of dependents per 100 workingage population.

The explanatory variable is refered to the quality of institutional framework, measured by the level of economic freedom. Economic freedom means the degree to which a market economy is in place, where the central components are voluntary exchange, free competition, and protection of persons and property (Gwartney, et al, 2004). Economic freedom is the condition in which individuals can act with maximum autonomy and minimum obstruction in the pursuit of their economic livelihood and greater prosperity (Miler, et al 2014). Economic freedom is a composite that attempts to characterize the degree to which an economy is a market economy - that is, the degree to which it entails the possibility of entering into voluntary contracts within the framework of a stable and predictable rule of law that upholds contracts and protects private property, with a limited degree of interventionism in the form of government ownership, regulations, and taxes (Berggren, 2003). To measure the level of economic freedom, we will use data from Fraiser institute. Variables description is provided in table 1.

Table 1. Variable desription

\begin{tabular}{|l|l|l|l|}
\hline Variables & Code & Description & Source \\
\hline $\begin{array}{l}\text { Total early-stage } \\
\text { entrepreneurship }\end{array}$ & $\log (\mathrm{TEA})$ & $\begin{array}{l}\text { The logarithm of the share of population } \\
\text { involved in early-stage entrepreneurship }\end{array}$ & GEM \\
\hline Economic growth & $\operatorname{dLog}(\mathrm{GDP})$ & $\begin{array}{l}\text { First logarithmic diference of GDP in con- } \\
\text { stant prices }\end{array}$ & IMF \\
\hline Economic freedom & $\log (\mathrm{EFI})$ & $\begin{array}{l}\text { The logarithm of Index of economic free- } \\
\text { dom }\end{array}$ & $\begin{array}{l}\text { Heritage } \\
\text { foundation }\end{array}$ \\
\hline GDP per capita & $\begin{array}{l}\log (\mathrm{GDP}- \\
\mathrm{pc})\end{array}$ & The logarithm of GDP per capita & IMF \\
\hline $\begin{array}{l}\text { The age dependency } \\
\text { ratio }\end{array}$ & $\log ($ age $)$ & The logarithm of The age dependency ratio & WB \\
\hline
\end{tabular}

Source. Author 


\section{DATA AND RESULTS}

The first step is to test variables for stationarity. The results fo unit root test are presented in tabel 2.

Table 2. Results of the unit root test

\begin{tabular}{|l|r|}
\hline Variable & $\mathrm{I}(\mathrm{d})$ \\
\hline $\log (\mathrm{GDP})$ & $\mathrm{I}(1)$ \\
\hline Log(tea $)$ & $\mathrm{I}(0)$ \\
\hline LOG(GDPPC $)$ & $\mathrm{I}(1)$ \\
\hline $\log (\mathrm{TEA})$ & $\mathrm{I}(0)$ \\
\hline $\log (\mathrm{EFI})$ & $\mathrm{I}(0)$ \\
\hline Log(age $)$ & $\mathrm{I}(1)$ \\
\hline
\end{tabular}

Source. Author

Three variables possess a unit root, so a usual OLS can not be applied. In this case we will apply a PMG/ARDL model. The descriptive statistic is presented in table 3.

Table 3. Descriptive statistic

\begin{tabular}{|l|l|l|l|l|l|}
\hline & GDP & GDPPC & EFI & TEA & AGE \\
\hline Mean & 1400.154 & 37036.76 & 7.100581 & 5.727613 & 51.14858 \\
\hline Median & 1555.009 & 36297.36 & 7.480000 & 5.510000 & 51.55849 \\
\hline Maximum & 4181.103 & 65481.78 & 8.410000 & 11.37000 & 59.30390 \\
\hline Minimum & 140.9290 & 24315.56 & 0.000000 & 1.630000 & 44.40105 \\
\hline Std. Dev. & 1022.083 & 6630.047 & 1.798068 & 1.784015 & 3.225934 \\
\hline Observations & 155 & 155 & 155 & 155 & 155 \\
\hline
\end{tabular}

Source. Author 
The relationship between the economic freedom and enterpreneural activity is presented in table 4 .

Table 4. Econometric analisys

Dependent Variable:

DLOG(TEA)

Method: ARDL

Date: 08/27/17 Time: 12:58

Sample: 20022014

Included observations: 130

Dependent lags: 1 (Fixed)

Dynamic regressors (1 lag, fixed): LOG(EFI) LOG(GDP-

PC) DLOG(GDP)

LOG(AGE)

Fixed regressors: C @TREND

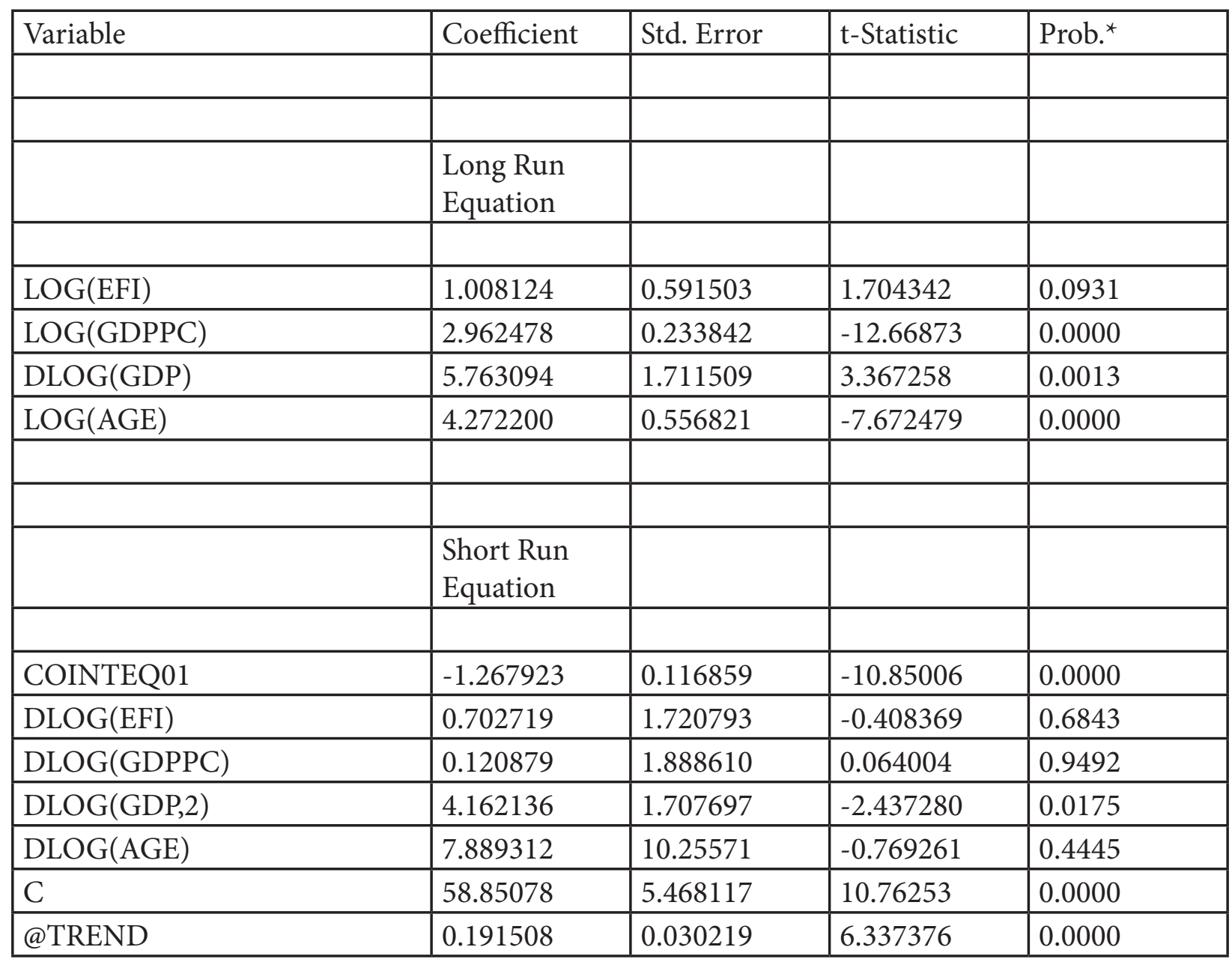

Source. Author 


\section{CONCLUSION}

In this paper, we have empirically analyzed the relationship between institutions of economic freedom and entrepreneurship. The relationship between economic freedom and the entrepreneurial activity has been described as the "missing link" in how economic freedom affects economic growth. All the previous work have investigated this topic on small country samples, in which most are rich countries (OECD and U.S. states). Our analysis is based on EU 11 countries, which can be described as a core capitalist countries. To test the impact of economic freedom on the entrepreneurial activity we have used data from Global Entrepreneurship Monitor to measure entrepreneurial activity. To measure the quality of institutional framework, we have used data from Fraiser Institute. Data on GDP per capita and GDP in constant prices are from IMF, and data on the age dependency ratio are from World Bank. Three variables have a unit root, so we can not use the ols method. In this case, we use a a PMG/ARDL model which enables us an insight into the long term and short term relationship. Long term equation suggests that economic freedom has a strong positive and statistically significant impact on entrepreneurial activity. All control variables, also have a positive and statistically significant impact on entrepreneurial activity. The cointegration is also statistically significant and negative, which means that long term relationship exists between the variables.

There is much scope for methodological advancements within this research field. The Economic theory starts to recognize the entrepreneurship as a key role in technological advancements and economic development. Creating the favorable rolls of the game, the rules which enhance entrepreneurial activity has become the central question for economists and governments. Future researchers of this study could include the same statistical analysis for the economic freedom index developed by The Heritage Foundation and for a new measure of opportunity based entrepreneurship, which will enable us to obtain new conclusions and at the same time contrasting the similarity or difference with those obtained in this work. 


\section{LITERATURE}

1. Baumol, W (1990). Entrepreneurship productive, unproductive, and destructive. Journal of Political Economy, 98 (5): 893-921.

2. Baumol, W. (1968). Entrepreneurship in economic theory. American Economic Review, 58 (2): 64-71.

3. Berggren, N. (2003): The Benefits of Economic Freedom: A Survey. The Independent Review, 8(2), 193-211.

4. Bjørnskov, C., \& Foss, N. J. (2008). Economic freedom and entrepreneurial activity: Some cross country evidence. Public Choice, 134 (3-4): 307-328.

5. Evans, D.S. \& Leighton, L.S. (1989b). The determinants of changes in U.S. self-employment, 1968-1987, Small Business Economics, 1 (2): 111-119. Global Entrepreneurship Monitor

6. Gwartney, J.D., \& Lawson, R.A. (2004). Economic freedom of the world: 2004 annual report. Vancouver: The Fraser Institute.

7. Hall, J. Nikolaev, B, Pulito, J. VanMetre, B (2013): Freedom and enterpreneurship, New evidence from 50 states, Americal journal of enterpreneurship, this issue,

8. Holcombe, R. (2007): Entrepreneurship and Economic Progress, New York: Routledge,

9. International Monetary Fund

10. Kreft, S.F., \& Sobel, R.S. (2005). Public policy, entrepreneurship, and economic freedom. Cato Journal, 25 (3): 595-616,

11. Miler, T. Kim, A. Holmes, K. (2014): Index of Economic Freedom. Washington, DC: The Heritage Foundation and Dow Jones \& Company, Inc

12. Nyström, K. (2008). The institutions of economic freedom and entrepreneurship: Evidence from panel data. Public Choice, 136 (3): 269-282.

13. Peters, M., Cressy, R.C. \& Storey, D.J. (1999). The Economic Impact of Ageing on Entrepreneurship and SMEs. Warwick/Zoetermeer: Warwick Business School/EIM.

14. Storey, D.J. (1994). Understanding the Small Business Sector. London: Routledge. The Fraiser institute

15. van Gelderen, M.W. (1999). Ontluikend ondernemerschap (Nascent Entrepreneurship). Zoetermeer: EIM Business and Policy Research.

16. Verheul, I., Wennekers, A. R. M., Audretsch, D. and Thurik, R. (2002). An Eclectic Theory of Entrepreneurship: Policies, Institutions and Culture. In: Audretsch, D., Thurik, R., Verheul, I., \& Wennekers A.R.M. (eds.), Entrepreneurship: Determinants and Policy in a European-US Comparison, Boston/Dordrecht: Kluwer Academic Publishers: 11-81. World Bank 